\title{
PERLINDUNGAN HUKUM KONSUMEN DALAM HAL PELAKU USAHA PENGEMBANG RUMAH SUSUN YANG SUDAH DINYATAKAN PALIT (STUDI TERHADAP KEMANGGISAN RESIDENCE)
}

\author{
Illona \\ (Mahasiswa Program S1 Fakultas Hukum Universitas Tarumanagara) \\ (Email: illona.j3@gmail.com)
}

\section{Anna Maria Tri Anggraini}

(Corresponding Author)

(Dosen Fakultas Hukum Universitas Trisakti, Meraih Sarjana Hukum dari Fakultas Hukum Universitas Gadjah Mada (1987), Magister Hukum dari Fakultas Hukum Universitas Tarumangara (1995), Doktor Ilmu Hukum dari Fakultas Hukum Universitas Indonesia (2003))

(Email: anggraini1601@gmail.com)

\begin{abstract}
The needs for apartment are currently increasing as the population increases and as availability of land becomes limited. The demand for such apartment is utilized by the developers to build and market the apartment in the community. However, with the high desire of developers in meeting the demands for apartment, it does not always coincide with the needs of the consumers for a decent place to live and have a guarantee of legal security. Therefore, the author proposes issue about how is the law protection of consumer in terms of apartment developers as business actors who have declared bankruptcy viewed from the perspective of Consumer Protection Law? The research method that the researcher uses for the issue is academy purposes methods with library data collection techniques. After conducted the research of preventive consumer legal protection, the law has been regulated in Regulation Number 8 Year 1999. But with Consumer Protection Act yet has not provided maximum protection to consumer. The violation of the consumer rights have given uncertainty to the consumers who will buy the apartment units. Plenty of developers whose business activities in the apartment field perform their activities with no good faith. While the repressive consumer legal protection has been regulated. The settlement can be done both inside and outside the court. However, the settlement has not been so regulated that it leaves a gap for business actors to avoid from responsibility to compensate consumers.
\end{abstract}

Keywords: Legal Protection, Consumer Protection, Bankruptcy, Developer, Apartment. 


\section{Pendahuluan}

\section{A. Latar Belakang}

Kegiatan bisnis merupakan bagian dari perekonomian yang mencakup aspekaspek yang sangat luas, karena menyangkut aspek-aspek yang sangat luas maka terdapat banyak hukum yang mengatur seputar kegiatan bisnis seperti hukum perusahaan, hukum ketenagakerjaan, hukum perlindungan konsumen, hukum mengenai properti, hukum asuransi, hukum jaminan, hukum kepailitan dan lainnya. Bisnis diartikan sebagai usaha dagang atau usaha komersial di dunia perdagangan bidang usaha. ${ }^{1)}$ Kegiatan bisnis lazimnya bisa dilakukan oleh perseorangan, namun dapat juga oleh suatu perkumpulan dalam arti perkumpulan yang berbentuk badan hukum maupun perkumpulan yang bukan berbadan hukum. $^{2)}$

Kegiatan bisnis berbentuk badan hukum yang sering kita jumpai pada sekarang ini adalah perusahaan pembangun perumahan disebut juga dengan pengembang properti atau property developer yang melakukan pembangunan terutama di bidang rumah susun yang sering diketahui sebagai rusun atau dikenal dengan sebutan apartemen. Karena pertumbuhan penduduk pada masa ini yang semakin padat, maka kebutuhan akan tempat tinggal semakin meningkat dan persediaan tanah semakin terbatas maka pembangunan rumah susun menjadi salah satu solusi untuk masalah tersebut. ${ }^{3)}$ Menurut Pasal 5 ayat (1) Peraturan Menteri Dalam Negeri No 5 Tahun 1974 Tentang Ketentuan-Ketentuan Mengenai Penyediaan dan Pemberian Tanah Untuk Keperluan Perusahaan, perusahaan pembangun perumahan (pengembang) adalah suatu perusahaan yang berusaha dalam bidang pembangunan perumahan dari berbagai jenis dalam jumlah yang besar, di atas suatu areal tanah yang akan merupakan suatu kesatuan lingkungan

1) Departemen Pendidikan dan Kebudayaan, Kamus Besar Bahasa Indonesia, Edisi ke-2, (Jakarta: Balai Pustaka, 1995), hal.138.

2) Richard Burton Simatupang, Aspek Hukum Dalam Bisnis, Cetakan ke-2. (Jakarta: Rineka Cipta, 2007), hal.2.

${ }^{3)}$ Urip Santoso, Hukum Perumahan, Cetakan ke-2, (Jakarta: Kencana Prenada Media Group, 2016), hal.401-402. 
permukiman, yang dilengkapi dengan prasarana-prasarana lingkungan dan fasilitas-fasilitas sosial yang diperlukan oleh masyarakat yang menghuninya. Pengembang dalam melakukan kegiatan usaha di bidang penyelenggaraan rusun dapat melakukan kegiatan antara lain kegiatan perencanaan, pembangunan, penguasaan dan pemanfaatan, pengelolaan, pemeliharaan dan perawatan, pengendalian, kelembagaan, pendanaan dan sistem pembiayaan. ${ }^{4)}$

Pengembang dalam melakukan kegiatan bisnisnya untuk mencari keuntungan akan melakukan pemasaran dan bahkan hingga penjualan berhubungan erat dengan hal perizinan yang untuk mana pengaturan mengenai hal-hal tersebut ada diatur dalam Undang-Undang Nomor 20 Tahun 2011 Tentang Rumah Susun (selanjutnya disingkat menjadi UU Rusun). karena erat hubungannya juga dengan hal perizinan. Salah satu pengaturan adalah dalam hal melakukan proses pemasaran awal (pre-project selling) yang dimungkinkan untuk dilakukan oleh perusahaan pengembang. Menurut Pasal 16 ayat (2) UU Rusun, proses pemasaran awal dapat dilaksanakan dengan ketentuan wajib menyediakan sekurangkurangnya $20 \%$ dari total luas lantai-lantai rumah susun yang akan dibangun. Ketentuan pasal ini jelas mengatur bahwa pengembang rusun dapat menawarkan unit-unit apartemen itu dengan ketentuan minimal keterbangunan 20\% dari total unit maupun sarana yang direncanakan dibuat.

Sering dalam penerapannya syarat $20 \%$ keterbangunan ini tidak dilaksanakan. Syarat ini dikesampingkan oleh perusahaan pengembang dalam proses pemasaran awal dengan menawarkan produknya kepada calon pembeli walaupun belum mendapatkan perizinan. Kemudian pemasaran tersebut terjadi penjualan unit-unit apartemen di mana pembayaran dari pembelian tersebut yang akan baru digunakan untuk menjadi modal tambahan dalam pembangunan apartemen yang dijanjikan. Dari penjualan tadi, terjadilah perjanjian antara

4) Indonesia, Undang-Undang Nomor 20 Tahun 2011 tentang Rumah Susun (Lembaran Negara Republik Indonesia Tahun 2011 Nomor 108, Tambahan Lembaran Negara Republik Indonesia Nomor 5252), Pasal 1 Ayat (2). 
pengembang dan pembeli yang dituangkan dalam Perjanjian Pengikatan Jual Beli (PPJB).

Seiring dengan pemasaran dan penjualan yang dilakukan, pembangunan apartemen berjalan sesuai dengan rencana. Akan tetapi kerap dijumpai kendala yang menghambat pembangunan yaitu beberapa developer mengalami masalah keuangan atau tidak dapat membayar utangnya sebelum menyelesaikan pembangunan apartemen. Dari berbagai faktor, salah satu penyebab utamanya adalah adanya hambatan dalam pemutaran keuangan (baik yang dilakukan oleh perusahaan sesuai maupun adanya itikad tidak baik dalam melakukan keuangan tersebut) atau mungkin mengalami kemunduran perusahaan yang mengakibatkan perusahaan pengembang tidak dapat membayar tagihan-tagihan perusahaan yang sudah jatuh tempo (adanya pinjaman kepada bank, jasa konstruksi, pekerja, dan lain-lain).

Berbagai langkah tentunya dilakukan untuk menyelesaikan permasalahan ini. Penyelesaiannya mengacu kepada undang-undang yang ada untuk mengatur halhal tersebut. Langkah yang dapat diambil dalam mengatasi masalah ini adalah dengan cara proses penundaan kewajiban pembayaran utang atau bahkan pailit. Seakan menjadi jalan keluar yang sangat mudah untuk menyelesaikan tagihantagihan yang sudah jatuh tempo tersebut kepailitan merupakan pilihan yang diajukan. Pailit merupakan suatu keadaan di mana debitor (dalam hal ini pengembang) tidak mampu untuk melakukan pembayaran-pembayaran terhadap utang-utang dari para kreditornya (pembeli unit apartemen). ${ }^{5)}$ Pengaturan mengenai Kepailitan dan Penundaan Kewajiban Pembayaran Utang (PKPU) sudah diatur di dalam Undang-Undang Nomor 37 Tahun 2004 Tentang Kepailitan dan Penundaan Kewajiban Pembayaran Utang (selanjutnya disingkat menjadi UUK).

${ }^{5)}$ M. Hadi Shubhan, Hukum Kepailitan Prinsip, Norma, dan Praktik di Peradilan, Cetakan ke-5, (Jakarta: Kencana Prenada Media Group, 2015), hal.1. 
Suatu hal yang tidak dapat dipungkiri bahwa perusahaan manapun dapat dinyatakan pailit dengan ketentuan yang diatur di dalam peraturan perundangundangan yang berlaku, termasuk perusahaan pengembang rusun. Tetapi tanpa disadari, putusan pailit suatu perusahaan pengembang rusun memberikan akibat yang besar bagi para pembeli yang dari awal membeli unit rusun dari perusahaan pengembang tersebut. Putusan pailit mengakibatkan seluruh aset perusahaan yang dinyatakan pailit diawasi, diambil alih dan disita untuk kepentingan pelunasan atau pembayaran utang kepada para kreditor. Terhadap tindakan ini, pembeli selaku konsumen dan juga yang merupakan salah satu kreditor pada dasarnya merupakan pihak yang sangat lemah dan dirugikan, karena tidak terpenuhinya hak-hak konsumen.

Para pembeli atau konsumen kemudian menuntut ganti rugi terhadap pembayaran pembelian unit apartemen kepada pihak pengembang properti sesuai dengan ketentuan yang berlaku agar para pembeli tidak lagi merasa rugi. Namun pembeli di dalam konsep hukum kepailitan dianggap sebagai kreditur konkuren atau tingkat kreditor yang paling rendah. Kreditor ini tidaklah cukup kuat untuk memperoleh pembayaran utangnya dari pihak perusahaan pengembang yang dipailitkan sebelum kreditor preferen dan kreditor separatis memperoleh pembayaran atas utangnya.

Dalam hal pengembang dinyatakan paiit, pembeli atau konsumen biasanya diposisikan sebagai kreditor konkuren. Posisi sebagai kreditor konkuren sangat merugikan konsumen, karena mereka akan ditempatkan sebagai urutan yang terakhir penerima pelunasan piutangnya setelah kreditur preferen. ${ }^{6)}$ Hak-hak pembeli tidaklah dipenuhi oleh pelaku usaha sebagaimana mestinya. Pelaku usaha seakan-akan melepas tanggung jawabnya terhadap konsumen karena adanya putusan pailit yang dijatuhkan kepada pelaku usaha pengembang properti.

6) Hilda B Alexander, "Kasus Kemanggisan Residence, Potret Lemahnya Posisi Tawar Konsumen", https://properti.kompas.com/read/2014/02/19/1829411/Kasus.Kemanggisan.Residence.Potret.Lemahn ya.Posisi.Tawar.Konsumen, diakses 07 April 2018. 
Sebuah kasus yang dapat dilihat adalah dalam kasus PT Mitra Safir Sejahtera. Pada tahun 2009, PT Mitra Safir Sejahtera (MSS) melakukan pembangunan apartemen dengan nama Kemanggisan Residence di daerah Kemanggisan. Dalam kegiatan transaksi jual-beli terhadap konsumen, PT MSS melakukan penjualan terhadap unit-unit apartemen yang kesepakatannya telah tertuang dalam perjanjian pengikatan dengan para konsumen yang dituangkan dalam Perjanjian Pengikatan Jual Beli (PPJB). ${ }^{7)}$

Namun pada tahun 2011, ketika bangunan (Tower A) sudah hampir selesai pembangunannya, PT MSS mengalami permasalahan finansial. Permasalahan finansial tersebut yang dikarenakan Direktur PT ini menyalahgunakan dana perusahaan diperuntukan untuk pembangunan yang mengakibatkan pembangunan menjadi tertunda dan kemudian berhenti sehingga tanggal penyerahan unit apartemen yang sudah diperjanjikan oleh kedua belah pihak, antara pengembang dan pembeli, tidak dapat dilakukan dan mundur. Tidak lama setelah itu, PT MSS melalui proses PKPU yang akan tetapi Pengadilan Negeri Niaga Jakarta Pusat menjatuhkan putusan pailit kepada PT Mitra Safir Sejahtera dengan Putusan Nomor: 28/PKPU/2011/PN.Niaga.Jkt.Pst. jo. Putusan Mahkamah Agung Nomor 253K/Pdt.Sus/2012. Akibatnya, kurang lebih 200 pembeli unit apartemen sebagai konsumen yang memiliki PPJB dan sudah membayar lunas unit apartemen yang dibelinya mengalami kerugian yang cukup besar. Atas kerugian ini kemudian para konsumen secara bersama-sama menuntut ganti kerugian kepada PT MSS dengan tuntutan pemberian ganti rugi penuh bagi para konsumen sesuai dengan harga yang sudah dibayarkan oleh para konsumen.

Berdasarkan uraian di atas, maka Penulis merasa tertarik untuk melakukan kajian secara komprehensif dan menuangkannya dalam proposal skripsi dengan judul "Perlindungan Hukum Konsumen Dalam Hal Pelaku Usaha Pengembang

7) Adi Suhendi, "Konsumen Rusunami Kemanggisan Residence Tuntut Hak", http://www.tribunnews.com/metropolitan/2014/02/19/konsumen-rusunami-kemanggisan-residencetuntut-hak, diakses 07 April 2018. 
Rumah Susun Yang Sudah Dinyatakan Pailit (Studi Terhadap Kemanggisan Residence)".

\section{B. Permasalahan}

Berdasarkan latar belakang yang telah dikemukakan di atas, maka dirumuskan permasalahan sebagai berikut: "Bagaimana perlindungan hukum konsumen dalam hal pelaku usaha pengembang rumah susun yang sudah dinyatakan pailit dari perspektif Hukum Perlindungan Konsumen?”

\section{Metode Penelitian}

Untuk membahas permasalahan dalam penelitian ini, Penulis menggunakan metode penelitian sebagai berikut:

1. Jenis Penelitian

Jenis penelitian yang dipergunakan dalam penyusunan proposal skripsi ini yaitu penelitian untuk keperluan akademis. ${ }^{8}$ Pendekatan yang digunakan dalam penelitian ini adalah pendekatan perundang-undangan (Statute Approach). ${ }^{9}$ Undang-undang yang akan digunakan dalam menelah isu hukum penelitian ini adalah UU No. 8 Tahun 1999 tentang Perlindungan Konsumen (selanjutnya disingkat UUPK) dan UU No. 37 Tahun 2007 tentang Kepailitan dan Penundaan Kewajiban Pembayaran Utang (selanjutnya disingkat UUK).

2. Sifat Penelitian

Sifat penelitian daripada penelitian ini adalah preskriptif, yaitu Penulis akan mencoba memberikan pemecahan permasalahan terhadap isu hukum dalam penelitian ini sehingga menghasilkan argumentasi atas hasil penelitian yang diperoleh, argumentasi tersebut berupa preskripsi atau penilaian mengenai benar atau salah, atau apa yang seyogianya menurut hukum terhadap fakta atau peristiwa hukum dari hasil penelitian. ${ }^{10)}$

3. Jenis Bahan Hukum

8) Peter Mahmud Marzuki, Penelitian Hukum, (Jakarta: Kencana Prenada Media Group, 2013), hal.225.

${ }^{9)}$ Ibid., hal.236. 
Penelitian ini menggunakan 2 (dua) macam jenis atau sumber bahan hukum yaitu bahan hukum primer dan bahan hukum sekunder. Karena Penulis menggunakan jenis penelitian untuk keperluan akademis menurut Peter Mahmud maka selanjutnya penyebutan jenis data menjadi sumber bahan hukum karena menurut penelitian hukum tidak mengenal adanya data. ${ }^{11)}$ Selain bahan hukum primer dan bahan hukum sekunder untuk melengkapi maka diperlukan juga bahan non-hukum yang semuanya akan diuraikan sebagai berikut yaitu:

a. Bahan hukum primer adalah bahan hukum yang bersifat autoritatif. ${ }^{12)}$ Bahan hukum primer juga dapat diartikan sebagai bahan-bahan hukum yang mengikat. ${ }^{13)}$ Contoh daripada bahan hukum primer adalah seperti perundangundangan ataupun traktat yang telah diratifikasi sehingga dapat dikatakan mengikat. Dalam penelitian ini bahan hukum primer yang digunakan adalah:

1) Kitab Undang-Undang Hukum Perdata;

2) Undang-Undang Nomor 8 Tahun 1999 Tentang Perlindungan Konsumen;

3) Undang-Undang Nomor 37 Tahun 2004 Tentang Kepailitan dan Penundaan Kewajiban Pembayaran Utang;

4) Undang-Undang Nomor 20 Tahun 2011 Tentang Rumas Susun;

5) Putusan Pengadilan Niaga Jakarta Pusat Nomor: 28/PKPU/2011/PN.Niaga.Jkt.Pst.;

6) Putusan Mahkamah Agung Nomor 253K/Pdt.Sus/2012.

b. Bahan hukum sekunder adalah bahan yang bersifat menjelaskan atau memberi keterangan atas bahan hukum primer, dalam hal ini bahan yang dimaksud adalah buku teks mengenai perlindungan konsumen, buku teks mengenai kepailitan dan bahan sejenis lainnya tentang perlindungan konsumen, kepailitan atau hal lain yang terkait dengan penelitian. Bahan hukum sekunder dalam penelitian ini bersumber dari buku, jurnal ilmiah, bahan yang diperoleh dari internet, teori atau pendapat para sarjana, makalah, dan surat kabar.

11) Ibid., hal.181.

12) Ibid., hal.181.

13) Amiruddin dan H. Zainal Asikin, Pengantar Metode Penelitian Hukum, Cetakan ke-1, (Jakarta: Raja Grafindo Persada, 2004), hal.31. 
c. Bahan non-hukum adalah bahan penunjang dari sumber hukum primer dan sekunder, sumber bahan non-hukum dapat berupa wawancara dengan narasumber (ahli hukum) sebagai upaya mendapatkan pendapat hukum tentang obyek yang diteliti, ataupun laporan-laporan penelitian non-hukum dan jurnal non-hukum sepanjang mempunyai relevansi dengan topik penulisan skripsi. ${ }^{14)}$ Dalam penelitian bahan non-hukum yang digunakan adalah wawancara yang akan dilakukan kepada narasumber di bidang perlindungan konsumen, kepailitan, dan pihak-pihak yang terkait dalam penelitian.

\section{Teknik Pengumpulan Bahan Hukum}

Teknik pengumpulan bahan pada penelitian adalah studi dokumen dengan metode deduktif. Studi dokumen adalah suatu alat pengumpulan bahan hukum dilakukan melalui bahan hukum tertulis. ${ }^{15)}$ Sedangkan metode deduktif berpangkal dari pengajuan premis mayor yaitu aturan hukum kemudian diajukan premis minor yaitu fakta hukum kemudian dari kedua hal tersebut ditarik suatu kesimpulan atau konklusi. ${ }^{16)}$

\section{Telaah Bahan Hukum}

Sesuai dengan jenis penelitian yang akan digunakan yaitu penelitian untuk keperluan akademis dan pendekatan yang digunakan yaitu pendekatan perundangundangan maka Peneliti akan melakukan telaah terhadap isu hukum yang dihadapi dan bahan-bahan hukum yang digunakan untuk mencapai tujuan daripada penelitian ini yaitu memberikan preskripsi yang dapat diterapkan. ${ }^{17)}$

\section{Pembahasan}

\footnotetext{
14) Peter Mahmud Marzuki, Op.Cit., hal.205.

15) Soerjono Soekanto, Pengantar Penelitian Hukum, Cetakan ke-3, (Jakarta: UI Press, 2005),

16) Op.Cit.,hal.90.

17) Ibid., hal.67-69.
} hal.66. 


\section{A. Perlindungan Hukum yang Bersifat Preventif Bagi Konsumen Dari Pelaku Usaha Pengembang Rumah Susun yang Sudah Dinyatakan Pailit}

Menyangkut mengenai bentuk perlindungan hukum untuk konsumen diketahui adanya dua sifat perlindungan hukum yaitu perlindungan hukum yang bersifat preventif dan perlindungan hukum yang bersifat represif. Perlindungan hukum bersifat preventif merupakan perlindungan hukum yang sifatnya pencegahan. ${ }^{18)}$ Dengan ini perlindungan hukum yang sifatnya preventif merupakan suatu yang pasti dan dibuat oleh pemerintah dalam suatu perundangundangan. $^{19)}$

Membicarakan mengenai perlindungan hukum bagi konsumen di Indonesia sudah diatur dalam UUPK. Secara garis besar UUPK telah mengatur mulai dari hak-hak konsumen dan pelaku usaha, kewajiban daripada konsumen itu sendiri maupun pelaku usaha, perbuatan apa saja yang dilanggar, tanggung jawab pelaku usaha, penyelesaian baik di dalam atau di luar pengadilan, dan juga lembagalembaga atau instansi-instansi yang terkait dalam menjalankan perlindungan terhadap konsumen. Akan tetapi walaupun sudah diatur dan ditetapkan melalui UUPK tetap saja ada terjadinya sengketa antara konsumen dan pelaku usaha dalam keduanya melakukan hubungan.

Sengketa-sengketa konsumen yang biasanya terjadi dikarenakan adanya hakhak konsumen yang dilanggar oleh pelaku usaha dalam menjalankan usahanya. Hal ini menjadi salah satu alasan mengapa diaturnya mengenai perlindungan terhadap konsumen. Posisi konsumen berada dalam posisi yang lemah dibandingkan dengan pelaku usaha. Sedangkan pelaku usaha yang memiliki posisi yang lebih kuat terkadang dalam melakukan usahanya tidak beritikad baik. Hak-hak konsumen yang dilanggar menyebabkan kerugian materil bagi

${ }^{18)}$ H. Salim HS dan Erlies Septiana Nurbani, Penerapan Teori Hukum Pada Penelitian Tesis dan Disertasi, Cetakan ke-1, (Jakarta: Raja Grafindo Persada, 2013), hal.264.

19) Ibid., hal.264. 
konsumen mulai dari skala kecil maupun besar. Meskipun demikian bukan berarti pelaku usaha juga tidak dapat dirugikan karena konsumen tidak beritikad baik.

Dalam Hukum Perlindungan Konsumen, ada 3 (tiga) fase atau tahapan transaksi dalam perlindungan konsumen dimana baik pelaku usaha maupun konsumen dapat melakukan itikad tidak baik yang menyebabkan terjadinya suatu sengketa. Ketiga tahapan tersebut adalah tahap pra transaksi, tahap transaksi dan tahap pasca transaksi. ${ }^{20)}$ Tahap pra-transaksi hanya dapat dilakukan oleh pelaku usaha. Pada tahap transaksi dan pasca transaksi dapat dilakukan baik oleh pelaku usaha maupun konsumen.

Seperti yang sudah diuraikan pada Latar Belakang PT MSS adalah pengembang rusun. Adapun uraian kasus Kemanggisan Residence dalam 3 (tiga) tahapan transaksi perlindungan konsumen adalah:

1. Tahap Pratransaksi

Tahap pertama yaitu tahap pratransaksi yang dimana sebelum terjadinya hubungan antara konsumen dan pelaku usaha. ${ }^{21)}$ Pengembang dalam tahap ini melakukan kegiatan usahanya sebelum terjadinya tahap jual-beli. Pada tahap ini pengembang berhubungan dengan hal-hal perizinan sebagaimana yang telah ditentukan dan diatur oleh peraturan yang ada. Kemudian salah satu kegiatan usaha yang dilakukan oleh pengembang adalah pemasaran awal atau yang diketahui sebagai pre-project selling.

Pemasaran awal dilakukan dengan syarat $20 \%$ keterbangunan dari total pembangunan yang akan dibangun sesuai yang diatur dalam Pasal 16 ayat (2) Undang-Undang No. 20 Tahun 2011 tentang Rumah Susun (UU Rusun). Banyaknya pengembang yang mengesampingkan syarat keterbangunan. PT MSS sebagai pengembang Kemanggisan Residence adalah salah satunya yang telah melakukan kegiatan pemasaran sebelum adanya keterbangunan $20 \%$.

20) Janus Sidabalok, Hukum Perlindungan Konsumen di Indonesia, Cetakan ke-3, (Bandung: PT Citra Aditya Bakri, 2014), hal.59.

21) Ibid., hal.59. 
Perihal pemasaran ini UUPK telah mengatur hal yang serupa dalam Pasal 9 ayat (1) huruf k yang berbunyi:

Pelaku usaha dilarang menawarkan, memproduksikan, mengiklankan suatu barang dan/atau secara tidak benar, dan/atau seolah-olah menawarkan sesuatu yang mengandung janji yang belum pasti.

dan Pasal 10 yang berbunyi:

Pelaku usaha dalam menawarkan barang dan/atau jasa yang ditujukan untuk diperdagangkan dilarang menawarkan, mempromosikan, mengiklankan atau membuat pernyataan yang tidak benar atau menyesatkan mengenai:

a. harga atau tarif suatu barang dan/atau jasa;

b. kegunaan suatu barang dan/atau jasa;

c. kondisi, tanggungan, jaminan, hak atau ganti rugi atas suatu barang dan/atau jasa;

d. tawaran potongan harga atau hadiah menarik yang ditawarkan.

e. bahaya penggunaan barang dan/atau jasa.

Perbuatan mengiklankan ini merupakan perbuatan yang dilarang dilakukan pelaku usaha oleh UUPK. Pengembang yang melakukan pemasaran awal tanpa adanya 20\% keterbangunan menawarkan sesuatu yang mengandung janji yang belum pasti. Bukan saja tidak pasti pengembang mengiklankan barangnya dengan kondisi yang tidak benar atau yang seharusnya.

2. Tahap Transaksi

Tahap transaksi terjadi pada saat adanya hubungan hukum antara pelaku usaha dan konsumen. Lahirnya kesepakatan pada tahap transaksi ini yang dituangkan dalam suatu perjanjian antara pelaku usaha dan konsumen. ${ }^{22)}$ Hubungan hukum antara PT MSS dan konsumen terjadi pada saat adanya transaksi jual-beli. Jual-beli tersebut melahirkan kesepakatan antara kedua belah pihak yang kemudian dituangkan dalam suatu perjanjian yaitu pembuatan PPJB antara pengembang dan pembeli.

\footnotetext{
${ }^{22)}$ Ibid., hal.61.
} 
PPJB yang merupakan perjanjian menimbukan prestasi timbal balik antara pengembang dan konsumen sebagai pembeli. ${ }^{23)}$ Pengembang memiliki hak maupun kewajiban begitu juga dengan konsumen yang memiliki hak maupun kewajiban. PT MSS berhak mendapatkan pembayaran atas penjualan unit-unit rusun dan juga berkewajiban untuk menyelesaikan pembangunan sampai konsumen mendapatkan barang yang diperjanjikan yaitu unit-unit rusun yang diperjual-belikan. Sebaliknya konsumen berhak atas unit rusun yang dibelinya dan berkwajiban untuk membayar secara penuh sesuai harga satuan unit rusun. PPJB dalam hal ini tidak dapat menjamin kepemilikan dari pembelian unit tersebut karena belum adanya AJB.

Konsumen dalam tahap ini menjalankan

3. Tahap Pasca Transaksi

Setelah tahap transaksi tahap yang terakhir adalah tahap pasca transaksi. Tahap ini jatuh pada pemenuhan dari prestasi setelah perjanjian dibuat pada tahap transaksi. ${ }^{24)}$ Banyak terjadinya sengketa konsumen pada tahap ini yang diakibatkan oleh salah satu pihak tidak memenuhi kewajibannya. Pada tahap pasca transaksi PT MSS tidak dapat memenuhi kewajibannya. Sebanyak 200 konsumen yang memiliki PPJB telah melakukan pembayaran penuh untuk unit rusun yang dibelinya tidak mendapatkan hak-haknya.

PT MSS tidak dapat memenuhi kewajibannya karena adanya permasalahan finansial. Maraknya pengembang untuk mencari keuntungan yang lebih besar yang diam-diam mengalihkan sebagian asetnya untuk pembangunan proyek lainnya. Alhasil proyek yang seharusnya dimana dana itu digunakan mengalami permasalahan keuangan dan tidak dapat melanjutkan pembangunan karena tidak membayar utang kepada kreditor. Permasalahan finansial tersebut mengakibatkan pengembang untuk mengambil jalan keluar yaitu mengajukan PKPU. PKPU kasus Kemanggisan

\footnotetext{
23) Ibid., hal.61.

24) Ibid., hal.61-63.
} 
Residence yang diajukan akan tetapi diputus pailit oleh Hakim Pengadilan Niaga.

Pailit dijadikan jalan keluar yang mudah apabila pengembang berada dalam keadaan finansial yang sulit. Sesuai dengan Pasal 2 UUK syarat pengajuan PKPU ataupun kepailitan adalah adanya 2 (dua) atau lebih kreditor dan utangnya tersebut sudah jatuh tempo. Pengembang berdasarkan pasal ini mengajukan PKPU atau langsung mengajukan kepailitan untuk menghindari tanggung jawab penyelesaian utangnya. Kebanyakan pengembang akan mengajukan kepailitan. Akibat dari proses kepailitan tersebut menempatkan seluruh harta berada di bawah pengawasan kurator. ${ }^{25)}$

Syarat pailit yang terpenuhi oleh pengembang merupakan solusi bagi pengembag akan tetapi bukan merupakan solusi terhadap konsumen. Kepailitan menempatkan konsumen yang membeli unit rusun menjadi kreditor konkuren atau kreditor yang paling akhir urutannya apabila terjadi pelunasan. $^{26)}$ Kreditor adalah orang yang mempunyai piutang karena perjanjian yang dapat ditagih di muka pengadilan. ${ }^{27)}$ Kreditor konkuren adalah kreditor yang akan mendapatkan pelunasan terhadap utangnya pada posisi paling terakhir. ${ }^{28)}$ Urutan pelunasan dalam kepailitan berurut mulai dari kreditor separatis, kreditor preferen, dan paling terakhir kreditur konkuren. Apabila pada saat pembagian pembayaran utang kreditur lainnya seperti separatis dan kreditur preferen sudah dibayarkan barulah utang kreditur konkuren dibayarkan itupun kalau ada sisa pembayaran. Hal ini menunjukkan bahwa konsumen meduduki posisi yang lemah dan terakhir dibandingkan dengan pelaku usaha, begitu juga mengalami kerugian.

${ }^{25)}$ Rahayu Hartini, Hukum Kepailitan, Cetakan ke-3, Edisi Revisi, (Malang: UMM Press, 2012), hal.88.

26) M. Hadi Shubhan, Op.Cit., hal.32.

27) Indonesia, Penjelasa Undang-Undang Nomor 37 Tahun 2004 tentang Kepailitan dan Penundaan Kewajiban Pembayaran Utang (Lembaran Negara Republik Indonesia Tahun 2004 Nomor 131, Tambahan Lembaran Negara Republik Indonesia Nomor 4443).

${ }^{28)}$ M. Hadi Shubhan, Op.Cit., hal.32-33. 
Dikenalnya prinsip pari passu prorate parte dalam kepaiilitan yang artinya bahwa harta kekayaan merupakan jaminan bersama untuk para kreditor tersebut dan hasilnya harus dibagikan secara proporsional. ${ }^{29)}$ Pembagian secara proposional terkesan adil namun perbuatan pengembang yang tidak beritikad baik telah merugikan konsumen dalam jumlah yang besar. Adanya ketidakpastian hukum bagi konsumen. Lain hal dengan pengembang yang merupakan pelaku usaha. Pelaku usaha dalam hal kepailitan merupakan debitur. Debitur adalah orang mempunyai utang karena perjanjian. ${ }^{30)}$ Pengembang PT MSS merupakan debitur yang sudah dinyatakan pailit atau debitur pailit.

Dari ketiga tahapan tersebut, perlindungan hukum konsumen dalam hal pengembang sudah dinyatakan pailit adanya ketidakpastian hukum bagi konsumen apalagi dalam hal ganti kerugian. Debitur pailit dalam hal ini adalah pelaku usaha yang adalah subjek daripada UUPK itu sendiri. Sesuai Pasal 1 Angka 3 UUPK disebutkan pelaku usaha ialah setiap orang perseorangan atau badan usaha, baik yang berbentuk badan hukum maupun bukan badan hukum yang didirikan dan berkedudukan atau melakukan kegiatan dalam wilayah hukum negara Republik Indonesia, baik sendiri maupun bersama-sama melalui perjanjian menyelenggarakan kegiatan usaha dalam berbagai bidang ekonomi. Kemudian kreditor konkuren Kemanggisan Residence masuk dalam pengaturan UUPK sebagai konsumen yang Pasal 1 Angka 2 UUPK adalah setiap orang pemakai barang dan/atau jasa yang tersedia dalam masyarakat, baik bagi kepentingan diri sendiri, keluarga, orang lain maupun mahluk hidup lain dan tidak untuk diperdagangkan. Berdasarkan kedua pasal UUPK tersebut hubungan antara PT MSS dan pembeli unit-unit rusun tersebut dapat dikategorikan sebagai hubungan antara pelaku usaha dengan konsumen (selanjutnya pembeli disebut sebagai

\footnotetext{
29) Ibid., hal.29.

${ }^{30)}$ Ibid., hal.29.
} 
konsumen) yang dimana PT MSS sebagai pelaku usaha wajib melakukan hak dan kewajiban yang diatur oleh UUPK begitu juga dengan konsumen.

Kasus Kemanggisan Residence menunjukan bahwa sengketa antara konsumen dengan pelaku usaha ini meletakan konsumen berada di posisi yang sangat lemah. Hal ini dapat di lihat dengan tidak terpenuhinya asas-asas perlindungan konsumen. Asas kepastian hukum dan keamanan dan keselamatan konsumen tidak dapat diberikan kepada konsumen. Ada hak-haknya dilanggar. Konsumen juga susah mendapatkan ganti rugi atau pembayaran karena adanya putusan pailit.pengaturannya sendiri telah diatur secara terpisah dalam UUK.

Permasalahan muncul pada saat perusahaan pengembang yang pada semulanya tidak terjadi apa-apa tiba-tiba mengalami masalah keuangan. Sebab terjadinya masalah keuangan tersebut terkadang muncul karena pengembang diam-diam menyalahgunakan dana proyek yang disalurkan kepada proyek lainnya untuk mencari keuntungan yang sebesar-besarnya. Masalah tersebut menyebabkan adanya utang-utang yang tidak dapat dibayarkan oleh pengembang untuk kelanjutan pembangunan rusun. Terhadap utang-utang tersebut jalan keluar yang sudah diatur tertera dalam UUK.

Kepailitan yang ditempuh oleh pengembang yang berakhir dengan pailitnya pengembang tersebut telah melanggar hak-hak konsumen dalam Pasal 4 UUPK huruf a, e, dan h. berikut uraiannya:

1. Pasal 4 UUPK huruf a

Konsumen tidak mendapatkan haknya untuk mendapatkan barang tersebut sesuai dengan kondisi yang dijanjikan. Kepailitan menempatkan harta pengembang berada di bawah pengawasan kurator yang kemudian setelah pailit konsumen konsum dalam hal pelunasannya.

2. Pasal 4 UUPK hurud e

Konsumen juga tidak mendapatkan kompensasi, ganti rugi dan atau penggantian apabila barang yang diterima tidak sesuai dengan sebagaimana mestinya.

3. Pasal 4 huruf $h$ 
Hak konsumen untuk mendapatkan advokasi, perlindungan, dan upaya penyelesaian sengketa perlindungan konsumen secara patut tidak dapat dilewati karena adanya pengaturan daripada pailit tersendiri.

Tidak hanya PT MSS telah melanggar hak-hak konsumen, sebagai pelaku usaha PT MSS tidak menjalankan kewajibannya yaitu menjalankan usahanya dengan itikad baik (Pasal UUPK). Begitu juga PT MSS selaku pengembang telah melakukan perbuatan yang dilarang oleh Pasal 16 UUPK yaitu:

Pelaku usaha dalam menawarkan barang melalui pesanan dilarang untuk:

1. Tidak menepati pesanan dan/atau kesepakatan waktu penyelesaian sesuai dengan yang dijanjikan;

2. Tidak menepati janji atas suatu pelayanan dan/atau prestasi.

Sejak proses pailit itu dimulai pengembang sudah kehilangan hak atas aset perusahaannya. Segala kepengurusan dan hak pengelolaan jatuh pada kurator dibawah pengawasan dari hakim pengawas. Jelas bahwa pengembang bebas dari tanggung jawab yang dinyatakan Pasal 16 UUPK padahal tindakan tersebut sangat merugikan banyak konsumen. Prestasi yang seharusnya wajib diberikan dalam waktu yang sudah ditentukan tidak terjadi.

Berdasarkan penjelasan di atas, perlindungan hukum secara preventif belum memberikan perlindungan secara maksimal bagi konsumen dalam bidang properti maupun menyangkut perihal kepailitan yang dialami oleh pelaku usaha. Bahwa di dalam hal pelaku usaha pengembang rusun yang sudah dinyatakan pailit sangat sekali merugikan konsumen dan kaitannya dengan rusun jumlah konsumen yang dirugikan bukan sedikit tetapi dalam jumlah besar. UUPK dan UUK adalah sebagai dua peraturan yang penyelesaiannya berbeda. Akan tetapi sebenarnya apabila dilihat keduanya dalam hal kasus pengembang rusun yang sudah dinyatakan pailit kedua peraturan tersebut saling memiliki keterkaitan.

Perlu adanya pengaturan lebih lanjut antara kepailitan dan perlindungan konsumen sehingga jelas pengaturan antara kedua bidang yang terkait. Pelaku usaha yang tidak beritikad baik lolos mempertanggungjawabkan perbuatannya. Banyaknya pelaku usaha yang bergerak di bidang properti (rusun) sengketa 
konsumen dalam bidang properti (rusun) pada era ini. Sebanyaknya 80\% dari total pengaduan yang masuk kepada BPKN menyangkut perihal perlindungan konsumen di bidang properti. ${ }^{31)}$

\section{B. Perlindungan Hukum yang Bersifat Represif Konsumen Dari Pelaku Usaha}

\section{Pengembang Rumah Susun yang Sudah Dinyatakan Pailit}

Setelah perlindungan hukum yang bersifat preventif selanjutnya akan dibahas perlindungan hukum yang bersifat represif. Perlindungan hukum yang bersifat represif berfungsi untuk menyelesaikan apabila terjadi sengketa. ${ }^{32)}$ Penyelesaian sengketa konsumen dapat ditempuh melalui litigasi yaitu melalui pengadilan atau non litigasi atau di luar pengadilan (Pasal 45 ayat (2) UUPK). Penyelesaian melalui pengadilan merupakan wewenang Pengadilan Negeri (PN) untuk mengadili. Hukum yang digunakan dalam beracara di Pengadilan Negeri untuk menyelesaikan sengketa konsumen mengacu pada ketentuan umum peradilan umum. Jadi hukum acara yang digunakan adalah hukum acara perdata untuk gugatan yang dilakukan. ${ }^{33)}$

Gugatan kepada PN ini dapat diajukan oleh seorang konsumen, pemerintah atau instansi, lembaga perlindungan konsumen swadaya masyarakat, atau juga sekelompok konsumen yang memiliki kepentingan yang sama. Hal ini diatur dalam Pasal 46 UUPK. Menyangkut gugatan yang dapat dilakukan sekelompok konsumen diakuinya adanya gugatan kelompok atau class action dalam UUPK. Gugatan kelompok tersebut hanya dapat diajukan kepada PN sama dengan gugatan yang diajukan oleh pemerintah karena biasanya menyangkut kepentingan umum dan lembaga perlindungan konsumen swadaya masyarakat.

Seiring dengan perkembangan penyelesaian ini banyak menjadi pilihan terakhir karena penyelesaiannya tergolong cukup lama, berbelit dan memakan

\footnotetext{
31) Berdasarkan Hasil Wawancara dengan Badan Perlindungan Konsumen Nasional (BPKN)..

${ }^{32)}$ H. Salim HS dan Erlies Septiana Nurbani, Op.Cit., hal.267-268.

33) Susanti Adi Nugroho, Proses-proses Sengketa Konsumen Ditinjau dari Hukum Acara Serta Kendala Implementasinya, Cetakan ke-2, (Jakarta: Kencana Prenada Media Group, 2011),
} hal.192. 
biaya yang besar apalagi apabila ternyata sengketa konsumen tersebut hanya menyangkut kerugian yang cukup kecil. ${ }^{34)}$ Maka dari itu diaturnya SCC yang penyelesaiannya tergolong cepat dan murah. SCC merupakan penyelesaian yang dapat diajukan kepada PN yang kerugian hanya sampai dengan 200 juta.

Setelah penyelesaian melalui pengadilan selanjutnya UUPK mengatur penyelesaian di luar pengadilan yang dapat diambil. Lembaga yang berwenang untuk menyelesaikan sengketa konsumen di luar pengadilan adalah Badan Penyelesaian Sengketa Konsumen (BPSK). BPSK dalam menyelesaikan sengketa konsumen mempunyai 3 (tiga) cara yaitu mediasi, konsiliasi, atau arbitrase. Putusan arbitrase yang dikeluarkan oleh BPSK merupakan putusan yang terakhir dan mengikat (final and binding) (Pasal 49 UUPK).

Dalam penyelesaian sengketa konsumen, UUPK menganut sistem pembuktian strict liability. ${ }^{35)}$ Pelaku usaha wajib membuktikan bahwa dirinya tidak bersalah. Hal ini untuk menyeimbangkan posisi antara kedua belah pihak. Konsumen dengan adanya sistem pembuktian ini diringankan dalam hal pembuktian karena diasumsikan konsumen berada dalam posisi yang lemah. Pelaku usaha yang diduga merugikan konsumen dapat dituntut dan dimintakan pertanggungjawabannya.

Berdasarkan kasus Kemanggisan Residence maka penyelesaian sengketa antara PT MSS dan konsumen dapat dilakukan baik melalui BPSK atau juga dilakukan melalui cara litigasi. Melihat kerugian terhadap konsumen dalam jumlah yang besar, konsumen yang dirugikan sejumlah kurang lebih 200 orang, dapat mengajukan gugatan kepada PN dengan cara class action. Class action dapat dilakukan dengan dasar gugatan yang sama yaitu ganti kerugian kepada PT MSS karena tidak memenuhi prestasinya.

34) Ibid., hal.85.

35) Shidarta, Hukum Perlindungan Konsumen Indonesia, Cetakan ke-3, Edisi Revisi II, (Jakarta: Grasindo, 2000), hal.73-78 
Selain class action konsumen dapat mengajukan gugatan SCC sesuai diaturnya dalam Peraturan Mahkamah Agung Nomor Nomor 1 Tahun 2002 Tentang Acara Gugatan Perwakilan Kelompok. Keuntungan SCC adalah penyelesaian yang cepat, singkat, dan biaya yang ringan. ${ }^{36)}$ Harga unit rusun yang dibeli oleh konsumen seharga kurang lebih 200 juta maka kerugian yang dialami oleh konsumen Kemanggisan Residence tersebut merupakan sengketa yang dapat diajukan melalui SCC kepada PN.

Konsumen Kemanggisan Residence pada nyatakan tidak melakukan upaya penyelesaian apapun melalui BPSK ataupun Pengadilan Negeri. Kurangnya pengetahuan terhadap penyelesaian yang memakai dasar hukum perlindungan konsumen mengakibatkan konsumen Kemanggisan Residence yang merasa dirugikan salah melakukan gugatan di PN yang kemudian gugur. Hal ini sering terjadi dalam kasus pengembang yang sudah dinyatakan pailit.

Sengketa konsumen dalam hal pengembang yang sudah dinyatakan pailit ini membuat perlindungan hukum represif secara Hukum Perlindungan Konsumen tidak dijalankan sama sekali. Konsumen pembeli yang mempunyai hak untuk mendapatkan penyelesaian dengan adil tidak mendapatkan keadilan tersebut untuk penyelesaian sengketa ini. Kepailitan yang seakan menjadi jalan keluar yang sangat mudah dijadikan cara untuk menghindari penggantian terhadap kerugian konsumen. Putusan pailit yang sudah ditetapkan Pengadilan Niaga terhadap PT MSS menyebabkan tidak adanya kepastian hukum bagi konsumen agar diberikan ganti rugi yang sudah dialami dan celah untuk pengembang dalam menghindari ganti rugi secara penuh.

Apabila diperhatikan UUPK belum secara jelas mengatur mengenai prosedur penyelesaian apabila terjadi sengketa dalam hal pengembang yang dinyatakan pailit akan tetapi pailit yang ditempuh oleh pelaku usaha merugikan konsumen dengan jumlah yang tidak sedikit. Sejalan dengan hasil wawancara yang

\footnotetext{
36) Susanti Adi Nugroho, Op.Cit., hal.192.
} 
didapatkan kepada Badan Perlindungan Kosumen Nasional (BPKN), dimana BPKN menyebutkan masih kurangnya pengaturan mengenai penyelesaian apabila terjadi kasus yang menyerupai. Ini menunjukan bahwa dalam penyelesaian sengketa yang mencakup hukum perlindungan konsumen dan kepailitan membuat suatu ketidakpastian hukum terhadap konsumen yang dirugikan dalam kasus pengembang dinyatakan pailit.

BPKN memiliki andil dalam melaksanakan perlindungan hukum konsumen. BPKN merupakan lembaga yang hanya dapat menerima pengaduan dari masyarakat tetapi tidak mengadili. Wewenang daripada BPKN terbatas hanya dengan menerima pengaduan dari masyarakat tetapi tidak mengadili.

BPKN dalam menanggapi aduan terhadap sengketa yang dialami akan menyelesaikannya melalui mediasi. Kedua belah pihak, baik konsumen maupun pelaku usaha akan di panggil untuk menyelesaikan sengketanya melalui musyawarah mufakat. Apabila mediasi yang dilakukan gagal, BPKN akan melanjutkan hal ini kepada BPSK atau PN untuk diselesaikan sesuai dengan hukum acaranya. Dalam hal ini BPKN merasa bahkan adanya pembatasan atau kewenangan yang sangat sempit dalam hal melakukan penyelesaian. Jalan keluar yang diharapkan terhadap sengketa ini BPKN menyarankan agar adanya revisi terhadap UUPK yang menyangkut mengenai kewenangan lembaga-lembaga di bidang konsumen terkait, terutama BPKN, dalam menyelesaikan sengketa.

Dari semua cara dalam menyelesaikan kasus ini maka diperlukannya pengaturan tentang bagaimana penyelesaiannya apabila suatu kasus tersebut diantara perlindungan konsumen dan kepailitan. Sebagai contoh kasus Kemanggisan Residence yang sengketanya kunjung belum terselesaikan. Konsumen dalam kasus ini terjebak sedangkan hal ini lebih menguntungkan terhadap pengembang yang tidak mempunyai itikad baik. Seharusnya UUPK sebagai payung dalam perlindungan konsumen dan semua hubungan yang 
meliputi hubungan antara konsumen dan pelaku usaha masuk dalam ranah pengaturan dari UUPK (Pasal 64 UUPK).

\section{PENUTUP}

\section{A. Kesimpulan}

Berdasarkan uraian dalam bab-bab sebelumnya dapat dikemukakan kesimpulan oleh penulis. Perlindungan hukum terbagi menjadi dua yaitu yang bersifat preventif dan represif. Di Indonesia, UUPK ialah undang-undang yang mengatur mengenai perlindungan hukum bagi konsumen. Ketiga tahapan transaksi antara PT MSS dan konsumen yang membeli rusun menunjukan perikaku itikad tidak baik pada fase pratransaksi, transaksi maupun pada tahap pasca transaksi. Hak-hak konsumen yang dilanggar terdapat pada Pasal 4 huruf a, e dan h. Perlindungan hukum bersifat preventif yang diatur dalam UUPK belum memberikan perlindungan secara maksimal. Adanya ketidakpastian bagi konsumen dalam pengaturannya begitu juga dengan ketidakamanan dalam membeli barang yaitu rusun.

Perlindungan hukum represif adalah cara untuk penyelesaian apabila terjadi sengketa. Cara penyelesaian yang bisa digunakan dalam kasus ini adalah penyelesaian sesuai dengan UUPK. Para konsumen dapat menempuh melalui pengadilan dengan 2 cara yaitu class action dan juga SCC. Akan tetapi konsumen Kemanggisan Residence tidak menempuh jalan penyelesaian ini. Dalam hal terjadinya kepailitan maka perlindungan hukum konsumen bagi para konsumen tersebut belum jelas diatur. Perlindungan hukum secara represif dalam hal kasus pengembang yang dinyatakan pailit meninggalkan celah bagi pengembang untuk bersembunyi dari pertanggungjawabnnya dalam terjadinya sengketa. Perlu adanya peraturan penyelesaian sengketa yang dapat menyelesaikan permasalahan ini.

\section{B. Saran}


Kepada masyarakat sebagai konsumen adalah untuk lebih mengutamakan kehati-hatian dan menjadi konsumen yang cerdas dalam hal pembelian rusun. Hal ini dapat mencegah kerugian konsumen karena maraknya pengembang yang melakukan kegiatan usahanya dengan tidak beritikad baik maka konsumen harus cerdas dalam mencari tahu mengenai barang atau produk yang akan dibelinya dalam kasus ini rusun. Bukan hanya cerdas konsumen harus berhati-hati dan mencari tahu mengenai pengembang tersebut mulai dari perizinan hingga kelayakan rusun.

Kepada pengembang sebaiknya melakukan kegiatan usahanya berdasarkan itikad baik untuk menghindari terjadinya kerugian yang dapat ditimbulkan dikemudian hari.

Kepada pemerintah hendaknya melakukan pengawasan pemasaran yang dilakukan oleh pengembang dan transaksi jual-beli rumah susun.

\section{DAFTAR PUSTAKA}

\section{A. Buku}

Diantha, I Made Pasek. Metodologi Penelitian Hukum Normatif Dalam Justifikasi Teori Hukum. (Jakarta: Kencana Prenada Media Group, 2016).

HS, Dr. H. Salim dan Erlies Septiana Nurbani. Penerapan Teori Hukum Pada Penelitian Tesis dan Disertasi. Cetakan Ke-1. (Jakarta: RajaGrafindo Persada, 2013).

Kristiyanti, Celina Tri Siwi. Hukum Perlindungan Konsumen. Edisi Ke-1. Cetakan Ke-3. (Jakarta: Sinar Grafika, 2011)

Marzuki, Peter Mahmud. Penelitian Hukum. Edisi Revisi. Cetakan Ke-8. (Jakarta: Kencana, 2013).

Miru, Ahmadi. Prinsip-prinsip Perlindungan Hukum bagi Konsumen di Indonesia. Cetakan Ke-2 (Jakarta: Rajawali Pers, 2013).

Miru, Ahmadi dan Sutarman Yodo. Hukum Perlindungan Konsumen. Cetakan Ke-9. (Jakarta: PT Raja Grafindo Persada, 2015).

Nasution, Az. Nasution. Hukum Perlindungan Konsumen Suatu Pengantar. Cetakan Ke-3. (Jakarta: Diadit Media).

Nugraha, Susanto Adi. Proses-proses Sengketa Konsumen Ditinjau dari Hukum Acara Serta Kendala Implementasinya. Cetakan Ke-2. (Jakarta: Kencana Prenada Media Group, 2011). 
Ramelan, Eman et al.. Perlindungan Hukum Bagi Konsumen Pembeli Satuan Rumah Susun/Strata Title/Apartemen. (Yogyakarta: Aswaja Pressindo, 2014).

Santoso, Urip. Hukum Perumahan. Cetakan Ke-2. (Jakarta: Kenana Prenada Media Group, 2016).

Shidarta. Hukum Perlindungan Konsumen Indonesia. Cetakan Ke-3. (Jakarta: PT Grasindo, 2006).

Shubhan, Dr. M. Hadi. Hukum Kepailitan Prinsip, Norma, dan Praktik di Peradilan. Cetakan Ke-5. (Jakarta: Kencana Prenada Media Group, 2015).

Sidabalok, Janus. Hukum Perlindungan Konsumen di Indonesia. Cetakan ke-3. (Bandung: PT Citra Aditya Bakri, 2014),

Soekanto, Soerjono. Pengantar Penelitian Hukum. Cetakan Ke-3. (Jakarta: UI Press, 2005).

Sutedi, Adrian. Tanggung Jawab Produk Dalam Hukum Perlindungan Konsumen. (Jakarta: Ghalia Indonesia, 2008). . Hukum Rumah Susun \& Apartemen. Cetakan Ke-2 (Jakarta: Sinar Grafika, 2012).

\section{B. Peraturan Perundang-undang}

Indonesia, Undang-Undang Nomor 37 Tahun 2004 tentang Kepailitan dan Penundaan Kewajiban Pembayaran Utang (Lembaran Negara Republik Indonesia Tahun 2004 Nomor 131, Tambahan Lembaran Negara Republik Indonesia Nomor 4443).

, Undang-Undang Nomor 8 Tahun 1999 tentang Perlindungan Konsumen (Lembaran Negara Republik Indonesia Tahun 1999 Nomor 22, Tambahan Lembaran Negara Republik Indonesia Nomor 3821).

, Undang-Undang Nomor 20 Tahun 2011 tentang Rumah Susun (Lembaran Negara Republik Indonesia Tahun 2011 Nomor 108, Tambahan Lembaran Negara Republik Indonesia Nomor 5252).

, Peraturan Mahkamah Agung Nomor 1 Tahun 2002 tentang Acara Gugatan Perwakilan Kelompok.

, Peraturan Mahkamah Agung Nomor 2 Tahun 2015 tentang Tata Cara Penyelesaian Gugatan Sederhana

, Peraturan Menteri Dalam Negeri No 5 Tahun 1974 tentang Ketentuan-Ketentuan Mengenai Penyediaan dan Pemberian Tanah Untuk Keperluan Perusahaan.

\section{Artikel, Makalah, dan Internet}

Adi Suhendi, "Konsumen Rusunami Kemanggisan Residence Tuntut Hak", http://www.tribunnews.com/metropolitan/2014/02/19/konsumenrusunami-kemanggisan-residence-tuntut-hak, diakses 07 April 2018.

Anonim, "Segudang Masalah Konsumen Perumahan", http://ylki.or.id/2011/10/segudang-masalah-konsumen-perumahan/, diakses 11 Juni 2018. 
Hilda B Alexander, “Kasus Kemanggisan Residence, Potret Lemahnya Posisi Tawar Konsumen", https://properti.kompas.com/read/2014/02/19/1829411/Kasus.Kemanggi san.Residence.Potret.Lemahnya.Posisi.Tawar.Konsumen, diakses 07 April 2018.

, "Banyak Konsumen Properti Terjebak Mafia Pailit". https://properti.kompas.com/read/2014/02/19/2003166/Waspada.Pailit.C uma.Akal-akalan.Pengembang. diakses 11 Juni 2018.

KonsPro, "Perjuangan Konsumen Akhirnya Berhasil, Apartemen Dukuh Golf Pailit Juga". http://konsumenproperti.com/sengketa/72-sengketa/184perjuangan-konsumen-akhirnya-berhasil-apartemen-dukuh-golf-pailitjuga-. diakses 29 Juni 2018.

Rivki, "Pengembang Apartemen Buah Batu Park Bandung Pailit". http://news.detik.com/berita/d-2920584/pengembang-apartemen-buahbatu-park-bandung-pailit. diakses 29 Juni 2018.

\section{Kamus}

Departemen Pendidikan dan Kebudayaan. Kamus Besar Bahasa Indonesia. Edisi Ke-2. (Jakarta: Balai Pustaka, 1995). 